\title{
CHARACTERIZATION OF ZINC OXIDE NANOPARTICLES SYNTHESIZED BY OLEA EUROPAEA LEAVES EXTRACT (PART L)
}
A. M. Al-Ghareebawi ${ }^{1}$
B. N. Al-Okaily ${ }^{2}$
Prof.
O. M. S. Ibrahim ${ }^{3}$
Researcher
Prof.

${ }^{1}$ Dept. Physiol. Biochem. and Pharmacol, Coll of Vet. Med., University of Thi-Qar, Iraq.

${ }^{2,3}$ Dept. Physiol. Biochem. and Pharmacol., Coll. of Vet. Med. University of Baghdad, Iraq.

ABYFA2017@gmail.com

\section{ABSTRACT}

The current study was aimed to synthesized zinc oxide nanoparticles (ZnONPs) using aqueous extract of olive leaves (OLE), which is very simple and eco-friendly method. ZnONPs were formed by dissolving of OLE in zinc oxide solution with adjusted $\mathrm{pH}$ to 12 . Zinc acetate dehydrate reduced to ZnONPs during mixing with OLE associated with change of the color solution from white to pale yellow color within a few minutes. The synthesized OLEZnONPs were separated by centrifugation $(4000 \mathrm{rpm} / 5 \mathrm{~min})$, then characterized by Fourier Transmission Infrared Spectroscopy (FT-IR), X-ray diffraction (XRD) and Field emissionScanning Electron Microscopy (FE-SEM) methods. The results of FT-IR showed that the functional group related to $\mathrm{Zn}-\mathrm{O}$ at $\left(433.98\right.$ to $\left.416.67 \mathrm{~cm}^{-1}\right)$, whereas $\mathrm{X}-\mathrm{RD}$ at 2 theta diagnose the type of oxide formation as $\mathrm{ZnO}$ and determined particle size in range $(20-30 \mathrm{~nm})$. Besides, SEM image was showed the presence of hexagonal shape of $\mathrm{ZnO}$ nanoparticles $(42.87 \mathrm{~nm})$. Therefore, the biogenic synthesis of zinc oxide nanoparticles using Olea Europaea leaves was simple, low coast, can be an alternative to chemical synthesis and the possibility of using in biomedicine field

Keywords | ZnONPs, Olive aqueous extract, Biosynthesis.

الغيباوي و آخرون

588-580:52: 52021 - مجلة العلوم الزراعية العراقية

توصيف الجسيمات النانويه لاوكسيد الزنك باستخدام مستخلص اورلق الزيتون (الجزء 1)

3

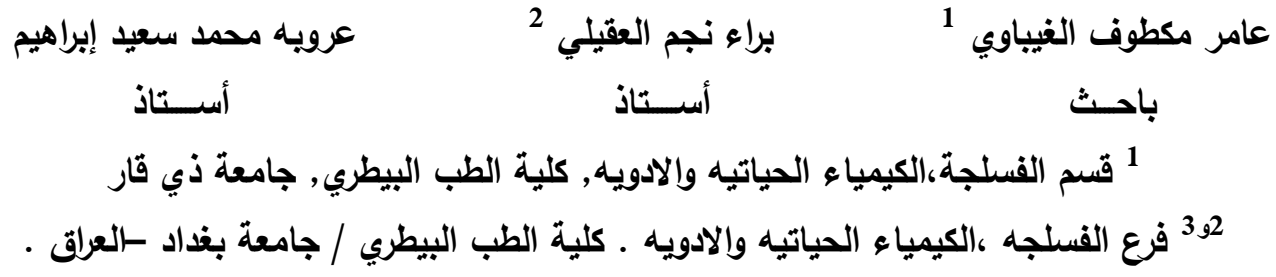

المستخلص

أستهدفت الاراسة الحالية إلى تخليق جسيمات أوكسيد الزنك النانوية (ZnONPs) باستخدام المستخلص المائي لأوراق الزيتون (OLE) ، وهي طريقة بسيطة للغاية وصديقة للبيئة. تم تثكيل دقائق أكسيد الزنك النانوية عن طريق إذابة OLE في التئية محلول أكسبد الزتك تدريجيا وعدلت درجة الحموضة (pH) إلى 12 واقترن ذلك بتغيير لون المحلول من الأبيض إلى اللون الأصفر الثاحب في غضون بضع دقائق. تم فصل ZnONPs المُصنَّعة بأستخدام الطرد المركزي ، ثم تم تمييزها بأستخدام تحويل طيف الاشعة تحت الحمراء (FT-IR) ، حيود الأثعة السينية (XRD) والمجهر الإكتروني المسحي (FE-SEM). أظهرت نتائج FT-IR أن المجموعة الوظيفية المرتبطة بـ Zn-O عند

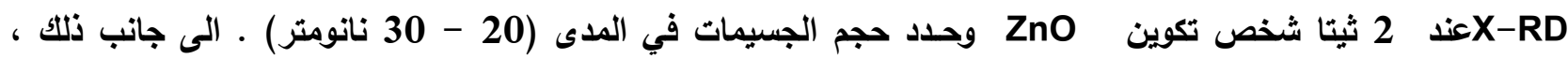
أظهرت صور والمجهر الإكتروني المسحي وجود شكل سداسي للجسيمات النانوية ويحجم 42.87 نانومتر. لذلك كان كان التخليق الحيوي لاقائق الزنك النانوية باستخدام أورلق الزيتون بسيطًا، منخفضً الكلفة، يمكن أن يكون بلئلاً عن التخليق

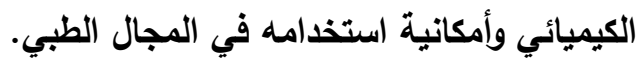
الكلمات المفتاحيه: دقائق الزتك النانوية، مستخلص الزيه فيتهال الزيتون المائي، التخليق ليحيوي . 


\section{INTRODUCTION}

The widespread description of nanotechnology (nanotech) is manipulation of matter on, molecular, supramolecular and atomic scale. Most nanoparticles are made up of a few hundred atoms with at least one dimension sized from 1 to 100 nanometers $(3,39,13)$. Technologies such as nanoparticles are being used to improve or replace todays therapies. Because of the properties of nanoparticles which allow it to affect the body differently than traditional therapies, so they are used, to an increase the brightness and clear image in ultrasound, to treating cancer through an increase the effectiveness of radiation therapy, to inhibit the bacterial reproduction and finally it could be used in orthopedic implants $(4,27)$. Also nanoparticles are used to an increase drug delivery because they can be sensitive to certain $\mathrm{pH}$ values, as well as theses nanostructured carriers should be able to protect drugs from enzymatic degradation to improve their penetration across the cell membrane and to modulate drug pharmacokinetics, thus improving efficacy and reducing drug toxicity (31). Zinc oxide nanoparticles (ZnONPs), in particularly, are environment friendly, display easy fabrication, non-toxic, bio-safe and biocompatible making them an typical candidate for biological implementations (36,24). Furthermore, according to the US Food and Drug Administration, Zinc Oxide $(\mathrm{ZnO})$ with other four zinc compounds have been recorded as mostly known as safe (GRAS) material (12). There have been recent reports on the biosynthesis of Zinc oxide nanoparticles using plants products like extracts such as leaves of Agathosma betulina (38) and (Camellia sinensis) (21). The main phytochemical molecules in plant extract mainly terpenoides, aldehydes, ketons, phenols and amides are responsible for nanoparticles synthesis $(5,37)$. The flavonoids, glycosides, proteins, and phenols in the Olive leaves (Olea europaea) played the spirited role to reduce zinc oxide when extract of olive leaves utilized (14). The synthesis of zinc oxide by olive leaves (Olea europaea) were give an end result of pale white and light brown precipitate respectively (30). This study was aimed to synthesized zinc oxide nanoparticles
(ZnONPs) using aqueous extract of Olive leaves (OLE), which is very simple and ecofriendly method.

\section{MATERIALS AND METHODS}

\section{Collection of olive leaves}

Olive leaves were obtained from Thi-Qar Governorate in September 2018. The leaves were identified and authenticated by special taxonomist at the National Herbarium of Iraq Botany Directorate in Abu-Gharib, under scientific name (Olea europaea) and belong to the family (Oleaceae) According to Book No. 2571 and dated on 24/6/ 2019.

\section{Preparation of aqueous extract of olive leaves}

The Olive leaves were collected, cleaned and washed two-times by water to remove the particles dust, Then, the leaves dried and grinded to fine powder by using electrical grinder. Ten grams of olive leaves powder was unsettled with $100 \mathrm{ml}$ of deionized water. The mixture was boiled for 10 min using a hot plate stirrer. After filtration, (by using gauze and filter paper), the OLE was cooled and stored in refrigerator $\left(4^{\circ} \mathrm{C}\right)$ for further usage $(19,41)$.

\section{Preparation and synthesis of zinc oxide nanoparticles}

Zinc Oxide Nanoparticles ( $\mathrm{ZnO}$ NPs) have been prepared by dissolving $0.25 \mathrm{~g}$ of zinc acetate dihydrate $\left[\mathrm{Zn}\left(\mathrm{CH}_{3} \mathrm{CO}_{2}\right)_{2} .2 \mathrm{H}_{2} \mathrm{O}\right](0.2$ $\mathrm{M})$ in $50 \mathrm{ml}$ deionized water. Then, $4 \mathrm{ml}$ of the aqueous OLE added drop by drop and the admixture was stirred for 10 minutes utilizing a magnetic stirrer. For adjusted $\mathrm{pH}$ of solution to $\mathrm{pH} \mathrm{12,} \mathrm{two} \mathrm{moles} \mathrm{of} \mathrm{sodium} \mathrm{hydroxide}$ $(\mathrm{NaOH})$ was added drop by drop during stirring till a pale yellow crystalline precipitate of zinc oxide was gained, which is washed 3 times frequently with water, clarified by $70 \%$ ethanol and finally filtrated and dehydrated in an oven at $60^{\circ} \mathrm{C}$ to gained the $\mathrm{ZnONPs}$ $(19,41)$.

\section{Separation and identification of zinc Oxide OLE Nanoparticles:}

X-ray Diffraction (XRD): X-Ray spectroscopy is very useful technique for characterization of different types of materials. Peaks of XRD are produced via constructive interference of a monochromatic beam of Xrays dispersed at specific angles from each set of lattice planes in a sample. The peak density 
is determined via distribution of atoms within the lattice. So, the XRD design is the fingerprint of periodic atomic arrangements in a given material (9). XRD spectrum of the designed $\mathrm{ZnO}$ nanoparticles was executed using XRD (XRD 6000 /Shimadzu/ Japan) in nanotechnology and advanced materials research center/ Technical University. for $2 \theta$ values ranging from 20 to $80^{\circ}$ using $\mathrm{CuK} \alpha$ radiation at $\lambda=1.5406 \AA$. The average particle size (D) of synthesized nanoparticles was calculated according to Debye-Scherrer equation (25).

\section{Fourier transform infrared (FT-IR) spectroscopy}

Fourier transform infrared spectroscopy FT-IR is widely used for chemical analysis of a biomedical samples (10) and detection the functional groups present in sample (17). For detection the workable groups on OLEZnONPs and identification their function in the synthesis of zinc nanoparticles, FT - IR analysis was performed(FTIR 8400S/Shimadzu / Japan) in nanotechnology and advanced materials research center/ Technical University.

\section{Scanning electron microscopy (SEM)}

A scanning electron microscope (SEM) is a one kind of electron microscope which produce figures of a sample (by scanning the surface with a focused beam of electrons). The atoms in the sample interact with electrons, resulting various signals which contain information for the surface topography and important composition of the sample (17). The suspended ZnONPs in sterile distilled water were utilized to scanning electron microscope analysis by fabricating a drop of suspension onto a cleanly electric stubs and permitting water to totally evaporate (7). Scanning electron microscopy analysis of synthesized ZnONPs was done in College of Science/ University of Babylon. Using SEM (Pharma /USA), under following condition signal $\mathrm{A}=\mathrm{SE} 2, \mathrm{EHT}=20.00 \mathrm{KV}, \mathrm{WD}=7.0 \mathrm{~mm}$.

\section{RESULTS AND DISCUSSION}

In the current study, biosynthesis of ZnONPs by utilization of OLE as a reducing agent causes change in color from white to pale yellow color within a few minutes after mixing figure (1A). In addition, the granules of the compound obtained after being placed in the oven $\left(60{ }^{\mathrm{O}} \mathrm{C}\right)$ was shown in the Figure(1B). The presence of different phytochemicals compounds in plant extracts such as phenols, terpenoids, ketones, aldehydes and amides are responsible for the nanoparticles synthesis (36), Bio-reduction involves reducing metal ions or metal oxides to 0 valence metal NPs with the help of phytochemicals like polysaccharides, polyphenolic compounds, vitamins, amino acids, alkaloids, terpenoids secreted from the plant $(16,33)$. Hashemi and his collogues (15) reported that glycosides, phenols, terpenoids, proteins, alkaloids and steroids was involve in O. europaea leaves extract and used in the synthesis of nanoparticles, served as reducing agents. Visual change in color and the formation of pale white precipitation is the preliminary analysis for green synthesis of nanoparticle indicated the successfully synthesis of OLEZnONPs $(1,14)$ using OLE as a precursor $(29,35)$. Besides, the increasing concentration of a plant extract caused decreasing in the size of synthesized NPs $(6,7)$. The reduction of metal ions resulted from transition of flavonoids from enol to the keto in order to formation of nanoparticles (33). Several studies have been demonstrated that flavonoids can be act as chelating compound that helped in understanding the role of flavonoids in initiation of nanomaterial formation and furthermore aggregation, and bio-reduction stage $(20,23)$. Other major controlling factors in bio-synthesis of nanoparticles are the $\mathrm{pH}$ and temperature of the reaction admixture. Thus, an increase in $\mathrm{pH}$ to 12 cause increase weight of $\mathrm{ZnONPs}$ as the final product of synthesis process, while more purity of $\mathrm{ZnONPs}$ are produced at lower $\mathrm{pH}$. In same way, temperature is recognized to be one of the main effector in the nanoparticles synthesis, it may also effect on color and weight of synthesized nanoparticles (18). 


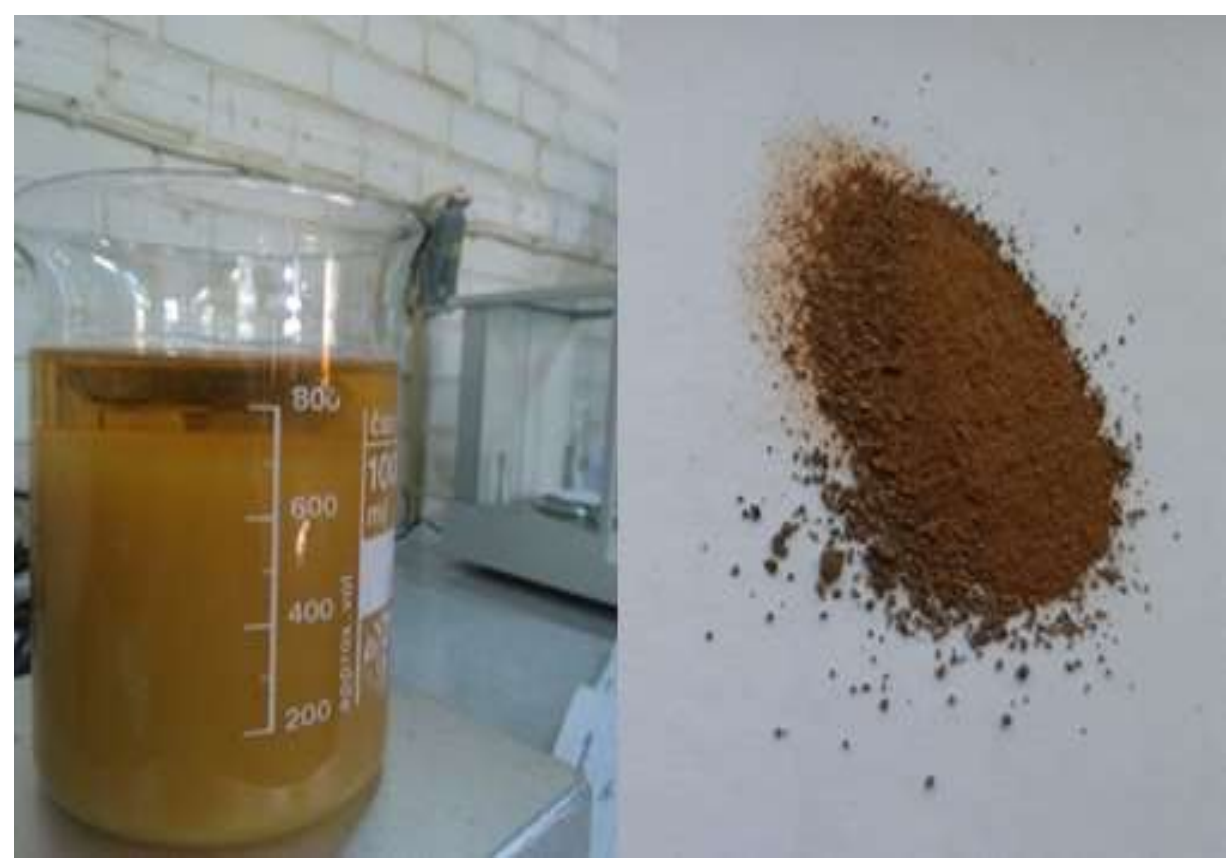

Figure 1. (A) shows participation of ZnO NPs after mixing with OLE and the color becomes pale yellow. (B) show $\mathrm{ZnO}$ nanopowder after drying in oven at $60{ }^{\circ} \mathrm{C}$.

FT-IR spectroscopy was used to set up the identity of different phytochemical constituents including the stabilization and reduction of the nanoparticles formation in the compound prepared from the reaction of zinc acetate dehydrate at alkaline $\mathrm{pH}(12)$. FT-IR spectroscopy pattern of OLEZnONPs as showed in figure (2) illustrated different peaks bands at $(3415.93,1579.70,1415.75,1492.90$, $1415.75,1074.35,433.96$, and $\left.416.62 \mathrm{~cm}^{-1}\right)$. FTIR- spectra is recorded to identify the functional groups on sample prepared. Also, the figure of FT-IR demonstrated the presence of several bands that indicate the present of $\mathrm{OH}$ C-C, C=O, C-H and $\mathrm{C}-\mathrm{N}$ as a functional groups on sample prepared. Herein, $\mathrm{O}-\mathrm{H}, \mathrm{C}-\mathrm{C}$, C-N and $\mathrm{ZnO}$ groups represent the presence of polyphenol, aromatic, alcohols and zinc oxide metal respectively. FT-IR spectrum showed strong absorption bands at (3415-3392 $\left.\mathrm{cm}^{-1}\right)$ is attributed to shows a wide and potent band at $3398 \mathrm{~cm}^{-1}$ is caused by bounded hydroxyl $(-\mathrm{OH})$ or amine $(-\mathrm{NH})$ groups of Olea europaea leaf extract , whereas, the band at 2953-2929 $\mathrm{cm}^{-1}$ is assigned to $\mathrm{C}-\mathrm{H}$ group as mentioned by Awwad (8) who showed the potent absorption peak at $2936 \mathrm{~cm}^{-1}$ could be assigned to $-\mathrm{CH}$ stretching vibrations of $-\mathrm{CH} 3$ and $-\mathrm{CH} 2$ workable groups. The peak at $1579 \mathrm{~cm}^{-1}$ may indicate to $\mathrm{C}=\mathrm{O}$ and $\mathrm{C}=\mathrm{C}$ as pointed and the stretching vibration at 1627 and $1506 \mathrm{~cm}-1$ band were attributed to $\mathrm{C}=\mathrm{O}$ and $\mathrm{C}=\mathrm{C}$, respectively (22). Meanwhile, Kaviyarasi and his colleague (19) reported that peak at 1588 $\mathrm{cm}^{-1}$ corresponds to $\mathrm{C}=\mathrm{O}$ stretching and $\mathrm{O}-\mathrm{H}$ stretching organic compound. Additionally, the absorption bands of the biomolecules utilized as reduction and stabilization(capping) agents, the absorption peak at $433 \mathrm{~cm}^{-1}$ was due to the availability of ZnONPs which is agreed with (41). The section among (500 and $\left.900 \mathrm{~cm}^{-1}\right)$ is concerning to metal oxygen, whilst the peaks at $\left(1634.00\right.$ and $\left.620.93 \mathrm{~cm}^{-1}\right)$ probably stand for $\mathrm{ZnO}$ stretching and deformation vibration, therefore FTIR spectrum proved that the $\mathrm{O}-\mathrm{H}$ stretching has a main role during the nanoparticles formation (17), in addition polyphenols act as the major stabilizing agents for nanoparticles which can be seen at $\left(3200-3500 \mathrm{~cm}^{-1}\right)$. Other peaks showed that ZnONPs were surrounded by proteins and metabolites. Carbonyl groups corresponding to amine acid residue and proteins have a high affinity to bond with metal ions $(2,10,42)$. 


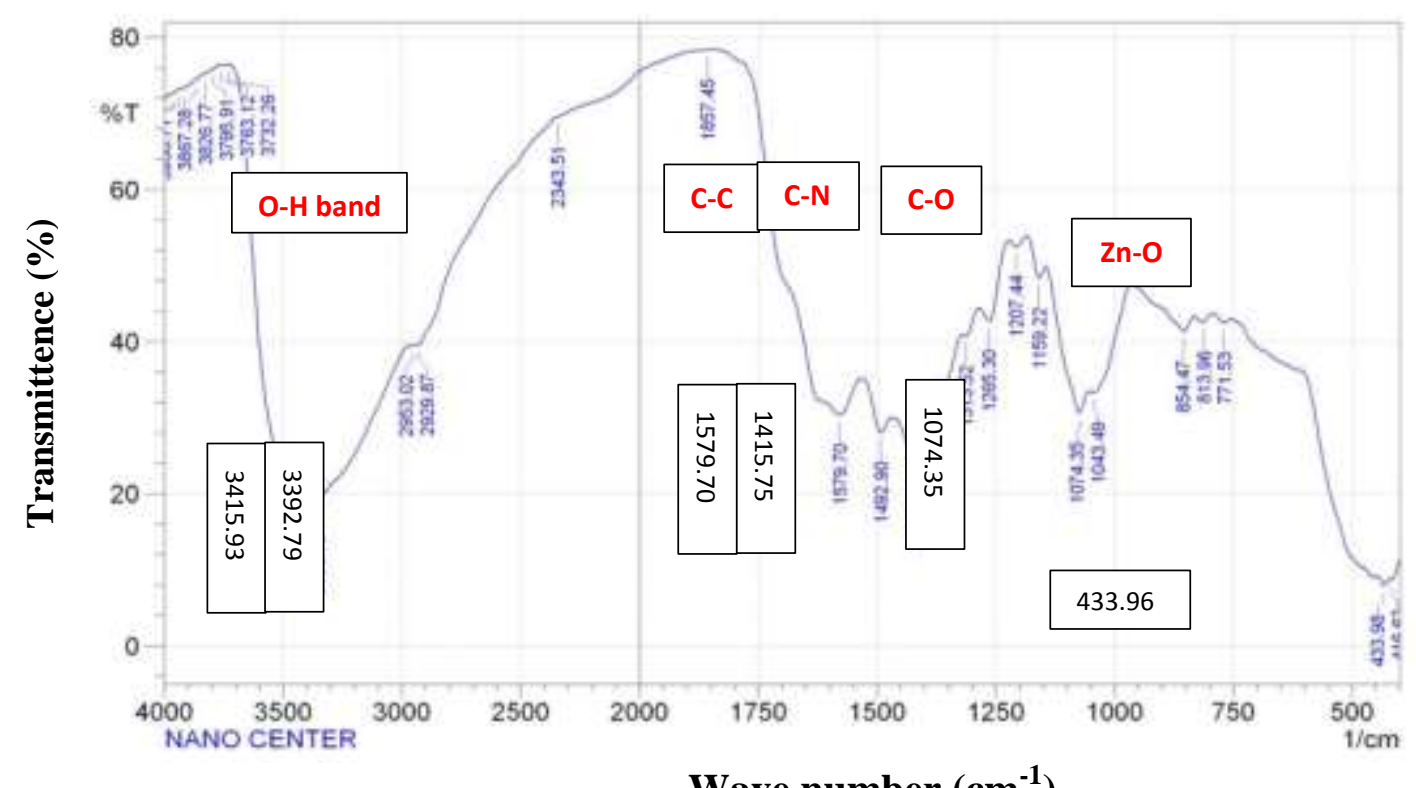

Wave number $\left(\mathrm{cm}^{-1}\right)$

Figure 2. FT-IR Spectrogram pattern of the synthesized ZnONPs using Olea Europaea leaves

Figure 3 demonstrat the characterization of $\mathrm{X}$ ray diffraction of ZnONPs synthesized by using OLE. XRD analysis provide information for diagnosis of type, size and crystallinity of nanoparticles. The results showed a pattern of XRD peaks at theta 2 values of $36.162^{\circ}$, $34.322^{\circ}, 31.683,47.50,62.90 .481,66.50$, $69.15,72.82$ and 77.10 corresponding to hkl values from 100, 002,101, 102, 110, 103, 200, 112 and 202 crystal plane was obtained . From the results the calculated value of $\mathrm{D}$ was $13.38 \mathrm{~nm}$. Accordingly, from FT-IR results, the soluble element appear in OLE could have served as capping agents and prevent the nanoparticles aggregation in solution and thus having a relevant role in their extracellular synthesis and shaping ( references ). The XRD pattern illustrated the orientation and crystalline nature of zinc oxide nanoparticles.
The peak position with $2 \theta$ values and hkl planes, In the XRD patterns, the (101) plane corresponding to $36.16^{\circ}$ was available to be very pure and plentiful which indicates preferential growth of the crystallites. The result indicated that utilizing OLE as a green synthesis reductant permit us to synthesize polycrystalline ZnONPs without the existence of another crystalline phase and without evidence of amorphous material, which makes this material comparable to $\mathrm{ZnONPs}$ gained by other plants $(36,37,38)$. Current resukts of XRD was in agreement with Hashemi (15) who exhibit the XRD manner of $\mathrm{ZnO}$ nanoparticles synthesised by olive leaves extract. Analysis of XRD spectra offered peaks at $2 \theta$ values, which matching to hexagonal structure of $\mathrm{ZnO}(\mathbf{4 1}, \mathbf{4 2})$. 


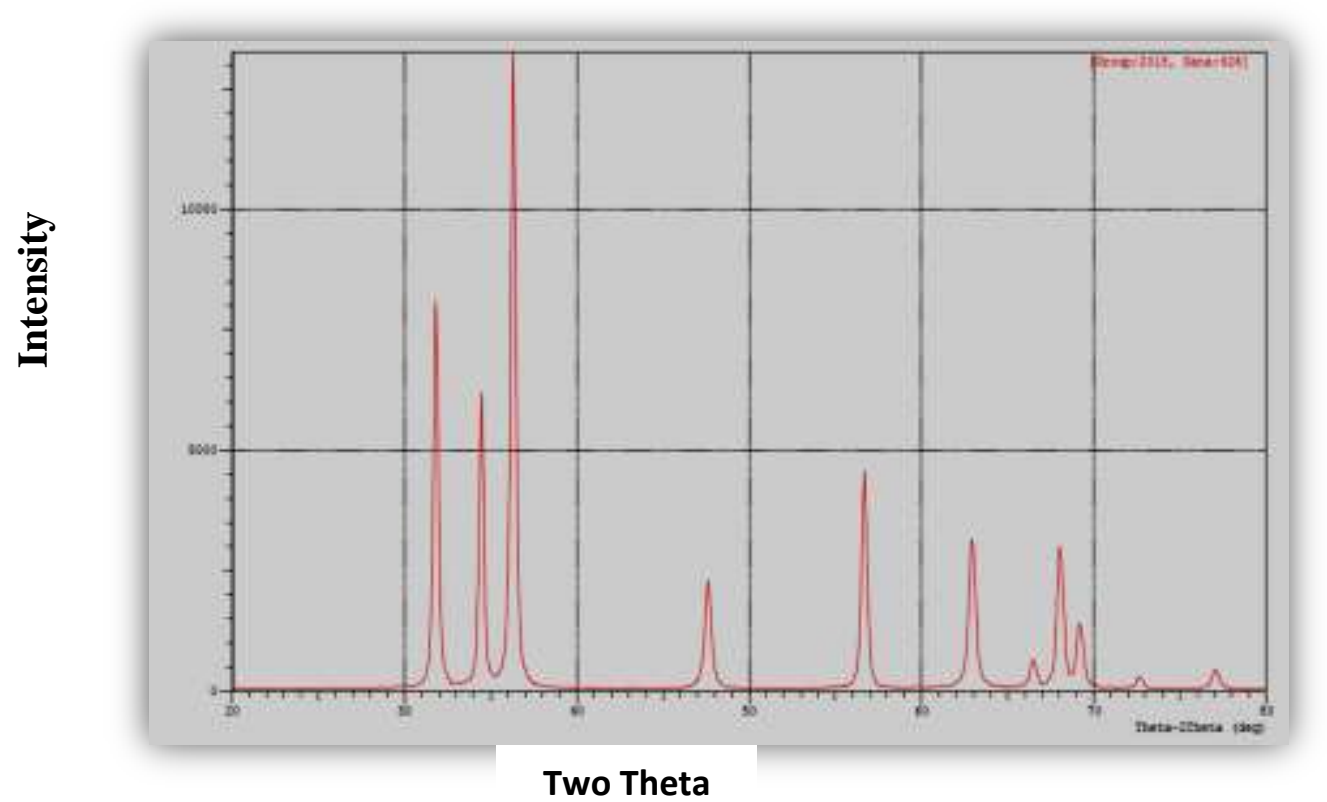

Figure 3. X-ray diffraction pattern of ZnONPs using Olea Europaea leaves

FE-SEM analysis is performed to visualize the morphological shape and size of OLEZnONPs that induced by reduction of zinc acetate dihydrate by OLE in $\mathrm{pH} 12$ in the present work. FE-SEM images that were seen at different magnification ranges $(200 \mathrm{~nm}-100$ $\mathrm{nm})$ demonstrated the presence of hexagonal shaped with a mean average diameter of $(42.87 \mathrm{~nm})$ for $\mathrm{ZnONPs}$ formed from OLE (figure $4 \mathrm{~A}$ and B). Analysis of SEM image was employed to further investigate the structural morphology and size of the nanoparticles that prepared in the present study. Green synthesis of ZnONPs from Olive Leaf extract appeared as self-aggregated in a close packed periodic array of hexagonal-like shape. Image of FE-SEM showed a different particle size of nanoparticles when compared with the result obtain from XRD analysis.
These changes may be the result of nanoparticles shape, due to the multipliers sample and not uniform on the size, thus only the particles on the surface of the sample can be measured by SEM. Whilst, the existence of negative charges on the nanoparticles surface as determined by zeta potential analysis will assist with the stability the soluble state and block their agglomeration by rising electrostatic repulsion between particles (32). However, many studies showed that this negative charges amount was not sufficient to stabilize nanoparticles sustainability, so that the residual nanoparticles in soluble state can cause more agglomeration and increase size of particles (34). In conclusion, green synthesis of $\mathrm{ZnO}$ nanoparticles using Olea europaea leaves extract provides an effective for ecofriendly method of synthesis of nanoparticles. 

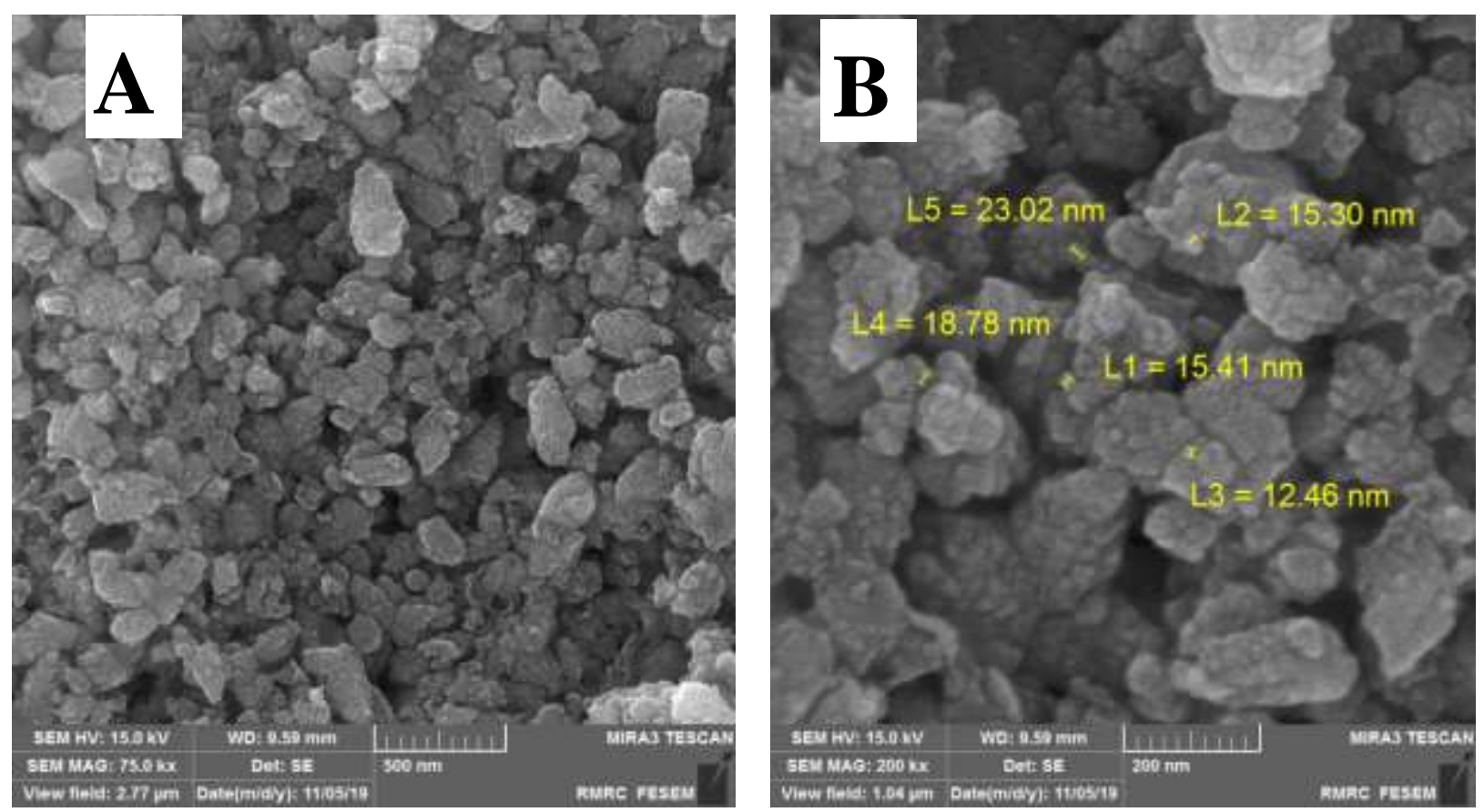

Figure 4. SEM image of ZnONPs synthesized using Olea Europaea leaves. (A) 500nm and (B) $200 \mathrm{~nm}$

\section{REFERENCES}

1. Agarwal, H., S.K. Venkat and S. Rajeshkumar. 2017. A review on green synthesis of zinc oxide nanoparticles - An eco-friendly approach. Resource-Efficient Technologies, 3(4): 406413.doi:10.1016/j.reffit.2017. 03.002

2. Ahmad N. A. Salih; O. M.S. Ibrahim and M.J. Eesa. 2017. Antibacterial activity of biosynthesized silver nanoparticles against pseudomonas aeruginosa in vitro. The Iraqi Journal of Veterinary Medicine, 41 (1):60-65

3. Ajayan, P.M.; L.S. Schadler and P.V. Braun 2003. Nanocomposite Science and Technology. Weinheim, Germany, WileyVCH Verlag GmbHand Co, KGaA

4. Al-Rudainy, A.J. and H.A. Khalel. 2019. Histopathological changes (Gills and Liver) and clinical signs of common carp , Cyprinus carpio L. exposed to graphene nanoparticles . Iraqi Journal of Agricultural Sciences. 50(3): 901-908

5. Al-Taee, E.H. 2020. Effect of silver nanoparticles synthesized using leaves extract of Olive on histopathological and cytogenetic effects in Albino mice. Iraqi Journal of Agricultural Sciences. 51(4): 901-908

6. Ambika, S. and M. Sundrarajan. 2015. Antibacterial behaviour of Vitex negundo extract assisted $\mathrm{ZnO}$ nanoparticles against pathogenic bacteria. J. Photochem Photobiol B.; 146:52-57

7. Anbuvannan, M.; M. Ramesh; G. Viruthagiri; N. Shanmugam and N. Kannadasan. 2015. Anisochilus carnosus leaf extract mediated synthesis of zinc oxide nanoparticles for antibacterial and photocatalytic activities, Mater. Sci. Semicond. Process; 39:621-628

8. Awwad, A.M.; N.M. Salem and A.O. Abdeen. 2012. Biosynthesis of Silver Nanoparticles using Olea europaea Leaves Extract and its Antibacterial Activity. Nanoscience and Nanotechnology; 2(6): 164170

9. Bunaciu, A.A.; E.G. Udriştioiub and H.Y. Aboul-Enein. 2015. X-Ray Diffraction: Instrumentation and Applications. Critical Reviews in Analytical Chemistry;45: 289-299 10. Chan, K.L.A and S.G. Kazarian. 2016. Attenuated total reflection Fourier-transform infrared (ATR-FTIR) imaging of tissues and live cells. Chem. Soc. Rev. 7;45(7):1850-1864. 11. Fazlzadeh, M.; R. Khosravi and A. Zarei. 2017. Green synthesis of zinc oxide nanoparticles using Peganum harmala seed extract, and loaded on Peganum harmala seed powdered activated carbon as new adsorbent for removal of $\mathrm{Cr}$ (VI) from aqueous solution. Eco. Eng.; 103:180-190 
12. FDA (Food and Drug Administration), Washington DC, USA, 2015. Select Committee on GRAS Substances (SCOGS) Opinion: Zinc Salts

13. Fritz, A.; L. Patrick and M. Daniel. 2010. What is nanotechnology and why does it matter?: from science to ethics. John Wiley and Sons.pp: 3-5.

14. Ghidan, A. Y.; T. M. Al-Antary; N. M. Salem and A. M. Awwad. 2017. Active Constituents of pomegranates (Punica granatum) as Potential candidates in the management of health through modulation of biological activities. J. of Agri. Sci.; 9(2): 131. 15. Hashemi, S.; Z. Asrar and S. Pourseyedi. 2016. Green synthesis of $\mathrm{ZnO}$ nanoparticles by olive (Olea europaea). Iet Nanobiotechnol; 10: 400-404

16. Heinlaan M.; A. Ivask; I. Blinova; H.C. Dubourguier; A. Kahru. 2008. Toxicity of nanosized and bulk $\mathrm{ZnO}, \mathrm{CuO}$ and $\mathrm{TiO} 2$ to bacteria Vibrio fischeri and crustaceans daphnia magna and thamnocephalus platyurus, Chemosphere 71 (2008) 1308-1316

17. Ishwarya, R.; B. Vaseeharan; S. Kalyani; B. Banumathi; M. Govindarajan; NS. Alharbi; S. Kadaikunnan; MN. Al-Anbr; JM. Khaled and G. Benelli. 2018. Facile green synthesis of zinc oxide nanoparticles using Ulva lactuca seaweed extract and evaluation of their photocatalytic, antibiofilm and insecticidal activity; J.Photochem. Photobiol. B.; 178: 249258 .

18. Jamdagni, P.; P. Khatri and J. S. Rana. 2018. Green synthesis of zinc oxide nanoparticles using flower extract of Nyctanthes arbor-tristis and their antifungal activity. J. of Kin. Sau. University-Science.; 30(2):168-175

19. Kaviyarasi, T.; B. Muthulakshmi and C. Kavitha. 2017. Green synthesis and characterization of zinc nanoparticle using aegle marmelos leaf extract. International Journal of ChemTech Research. 1(15), 344348

20. Khatoon, N.; J. A. Mazumder and M. Sardar. 2017. Biotechnological applications of green synthesized silver nanoparticles. J. of Nano.: Current Research Khatoon J Nanosci Curr Res J Nanosci Curr Res.; 2(2):1-8

21. Kumar, S.; P. Venkateswarlu; V. Rao and GN. Rao. 2013. 'Synthesis, characterization and optical properties of zinc oxide nanoparticles', Int. Nano. Lett.; 3(1): 1-6 22. Luo, F.; D. Yang and Z. Chen. 2016. Onestep green synthesis of bimetallic $\mathrm{Fe} / \mathrm{Pd}$ nanoparticles used to degrade Orange II. J Hazard Mater.;13(303):145-53

23. Makarov, V. V.; A. J. Love; O. V. Sinitsyna; S. S. Makarova; I. V. Yaminsky; M. E. Taliansky and N. O. Kalinina 2014. Rapid Green synthesis of zinc oxide nanoparticles using kedrostis foetidissima (Jacq.) cogn Leaf. Acta Naturae (Англоязычная Версия), 6 (1): 20

24. Mohammad, V.; A. Umar. and YB. Hahn. 2010. ZnO Nanoparticles: Growth, Properties, and Applications. In: Umar, A., Hahn, Y.B . Eds.), Metal oxide nanostructures and their applications. American Scientific Publishers, USA, pp. 1-36

25. Muniz, F.T.L.; M.A.L.R. Miranda; C.M. dos Santos, and J.M. Sasaki. 2016. The Scherrer equation and the dynamical theory of X-ray diffraction Acta Cryst.; A72.

26. Narendhran, S. and R. Sivaraj. 2016. Biogenic $\mathrm{ZnO}$ nanoparticles synthesized using L. aculeata leaf extract and their antifungal activity against plant fungal pathogens. Bulletin of Materials Science; 39(1): 1-5

27. Nasimi, P. and M. Haidari., 2013. Medical use of nanoparticles drug delivery and diagnosis diseases. International Journal of Green Nanoparticles. First Published. https://doi.org/10.1177/1943089213506978

28. Nava, O. J.; P. A. Luque; C. M. GómezGutiérrez; A. R.Vilchis-Nestor; A. CastroBeltrán; M. L. Mota-González and A. Olivas. 2017. Influence of Camellia sinensis extract on Zinc Oxide nanoparticle green synthesis. J. of Mol. Str.; 1134: 121-125

29. Ochieng, P.E.; E. Iwuoha; I. Michira; M. Masikini; J. Ondiek and P. Githira. 2015. Green route synthesis and characterization of $\mathrm{ZnO}$ nanoparticles using Spathodea campanulata, Int. J. Biochem. Phys.; 23; 5361

30. Ogunyemi, SO.; Y. Abdallah; M. Zhang; H. Fouad; X. Hong; E. Ibrahim; MI. Masum; A. Hossain; J. Mo and B. B. Li. 2019. Green synthesis of zinc oxide nanoparticles using different plant extracts and their antibacterial activity against Xanthomonas oryzae pv. 
Oryzae. Artificial Cells, Nanomedicine and Biotechnology; 47(1): 341-352

31. Parveen, A.; A.S. Roy and S. Roa. 2012. Biosynthesis and characterization of silver nanoparticles fron cassia auriculata leaf extract and in vivo evaluation of antimicrobial activity. IJABPT., 3:222-228.

32. Periyathambi, P.; W. S. Vedakumari; S. Bojja; S. B. Kumar and T. P. Sastry. 2014. Green biosynthesis and characterization of fibrin functionalized iron oxide nanoparticles with MRI sensitivity and increased cellular internalization. Materials Chemistry and Physics; 148(3): 1212-1220

33. Qu, J.; X. Yuan; X. Wang and P. Shao .2011. Zinc accumulation and synthesis of $\mathrm{ZnO}$ nanoparticles using Physalis alkekengi L. Environ Pollut.;159 (7):1783-1788

34. Rajendran, K.; V. Karunagaran; B. Mahanty and S. Sen. 2015. Biosynthesis of hematite nanoparticles and its cytotoxic effect on HepG2 cancer cells. Int. J. of Bio. Macromolecules; 74: 376-381

35. Rajeshkumar, S.; C. Malarkodi; M. Vanaja and G. Annadurai. 2016. Anticancer and enhanced antimicrobial activity of biosynthesizd silver nanoparticles against clinical pathogens, J. Mol. Struct. 1116 (2016) 165-173
36. Rosi, NL. and CA. Mirkin. 2005. Nanostructures in biodiagnostics. Chem. Rev.; 105 (4): 1547-1562

37. Sundrarajan, M. and S. Gowri. 2011. Green synthesis of titanium dioxide nanoparticles by Nyctanthes Arbor-Tristis leaves extract. Chalcogenide Lett.; 8 (8):447451

38. Thema, FT.; E. Manikandan; MS. Dhlamini and M. Maaza. 2015. Green synthesis of zno nanoparticles via agathosma betulina natural extract. Mater. Lett.; 161: 124-127

39. Thrall, J. H. 2004. Nanotechnology and Medicine. Radiology, 230: 315-318

40. Vanathi, P.; P. Rajiv; S. Narendhran; S. Rajeshwari; P.K.S.M. Rahman and R. Venckatesh. 2014. Biosynthesis and characterization of phyto mediated zinc oxide nanoparticles: A green chemistry approach. Materials Letters; 134: 13-15

41. Varghese, E. and M. George. 2015. Green synthesis of zinc oxide nanoparticles. IJARSE.; 4(1), 307-314

42. Wassan M. H.; J. K. Araak and O.M.S. Ibrahim. 2019. Green Synthesis of zinc oxide Nanoparticles from (punica granatum L) pomegranate Aqueous peel Extract. The Iraqi Journal of Veterinary Medicine, 43(2): 6-14. 